\title{
Release of $\mathrm{Ca}^{2+}$ by inositol 1,4,5-trisphosphate in platelet membrane vesicles is not dependent on cyclic AMP-dependent protein kinase
}

\author{
Flavia O'ROURKE, George B. ZAVOICO* and Maurice B. FEINSTEIN \\ Department of Pharmacology, University of Connecticut Health Center, Farmington, CT 06032, U.S.A.
}

\begin{abstract}
In contrast with previous reports, it was found that membrane-protein phosphorylation by the catalytic subunit (CS) of cyclic AMP-dependent protein kinase had no effect on $\mathrm{Ca}^{2+}$ uptake into platelet membrane vesicles or on subsequent $\mathrm{Ca}^{2+}$ release by inositol 1,4,5-trisphosphate $\left(\mathrm{IP}_{3}\right)$. Furthermore, IP-20, a highly potent synthetic peptide inhibitor of CS, which totally abolished membrane protein phosphorylation by endogenous or exogenous CS, also had no effect on either $\mathrm{Ca}^{2+}$ uptake or release by $\mathrm{IP}_{3}$. Commercial preparations of protein kinase inhibitor protein (PKI) usually had no effect, but one preparation partially inhibited $\mathrm{Ca}^{2+}$ uptake, which is attributable to the gross impurity of the commercial PKI preparation. $\mathrm{IP}_{3}{ }^{-}$ induced release of $\mathrm{Ca}^{2+}$ was also unaffected by the absence of ATP from the medium, supporting the conclusion that $\mathrm{Ca}^{2+}$ release by $\mathrm{IP}_{3}$ does not require the phosphorylation of membrane protein.
\end{abstract}

\section{INTRODUCTION}

In platelets $\mathrm{IP}_{3}$ formed in response to certain stimuli is believed to be a second messenger that can release $\mathrm{Ca}^{2+}$ from intracellular membrane stores (O'Rourke et al., 1985; Adunyah \& Dean, 1985; Authi \& Crawford, 1985). The catalytic subunit (CS) of cyclic AMPdependent protein kinase was reported to be facilitatory, or even necessary, for $\mathrm{Ca}^{2+}$ release by $\mathrm{IP}_{3}$ from isolated platelet membrane vesicles (Enouf et al., 1987). This conclusion was based on two observations; first, IP $_{3}$ released more $\mathrm{Ca}^{2+}$ when vesicles were exposed to $\mathrm{CS}$ during $\mathrm{Ca}^{2+}$ uptake, and secondly, a protein inhibitor of cyclic AMP-dependent protein kinase, originally described by Ashby \& Walsh (1972), counteracted these effects of exogenous CS. When tested in the absence of exogenous CS the protein kinase inhibitor (PKI) completely abolished the release of $\mathrm{Ca}^{2+}$ by $\mathrm{IP}_{3}$ (Enouf et al., 1987). From the latter finding it could be concluded that endogenous cyclic AMP-dependent protein kinase was necessary for the $\mathrm{Ca}^{2+}$-releasing action of $\mathrm{IP}_{3}$. PKI has also been reported to suppress $\mathrm{Ca}^{2+}$ uptake strongly (Hettasch \& LeBreton, 1987; Adunyah \& Dean, 1987), and in one case actually to cause substantial $\mathrm{Ca}^{2+}$ loss from vesicles (Hettasch \& LeBreton, 1987). The latter observation conflicts with the inhibition of $\mathrm{Ca}^{2+}$ release by PKI described by Enouf et al. (1987).

Other results all implicate cyclic AMP-dependent kinase in the regulation of $\mathrm{Ca}^{2+}$ uptake also. Several laboratories have observed that $\mathrm{CS}$ stimulated $\mathrm{Ca}^{2+}$ uptake by the platelet-membrane vesicles that are believed to be derived from the dense tubular system of platelets (Kaser-Glanzmann et al., 1977, 1979; Adunyah \& Dean, 1987; Hettasch \& LeBreton, 1987; Enouf et al., 1987). The effects of $\mathrm{CS}$ on $\mathrm{Ca}^{2+}$ uptake and release were correlated with the phosphorylation of a $23 \mathrm{kDa}$ polypeptide. It was suggested that this polypeptide may be phospholamban (Kaser-Glanzmann et al., 1979;
Adunyah \& Dean, 1987), a known promoter of $\mathrm{Ca}^{2+}$ transport in cardiac-muscle membranes, but that identity was disputed (LePeuch et al., 1983).

The hypothesis that $\mathrm{CS}$ promotes $\mathrm{Ca}^{2+}$ release by $\mathrm{IP}_{3}$ runs counter to the effects of cyclic AMP on free intracellular $\mathrm{Ca}^{2+}$ concentrations in intact platelets. Dibutyryl cyclic AMP, and various prostaglandins and forskolin, which stimulate adenylate cyclase, strongly antagonize and reverse the $\mathrm{Ca}^{2+}$ mobilization produced by platelet agonists (Rink \& Smith, 1983; Yamanishi et al., 1983; Feinstein et al., 1983, 1985). Furthermore, $\mathrm{Ca}^{2+}$ release by $\mathrm{IP}_{3}$ was reported not to require ATP (Adunyah \& Dean, 1986b; Meyer et al., 1988), and did not display the temperature-sensitivity expected of an enzymic process (Adunyah \& Dean, 1986b). Because of these conflicting findings, we have investigated the effects of $\mathrm{CS}$ on the $\mathrm{Ca}^{2+}$ uptake and release processes. In addition to PKI, we also employed a highly purified peptide inhibitor of CS. The synthetic peptide termed IP20 (see the Materials and methods section for its amino acid sequence) represents the active site of the skeletalmuscle protein inhibitor of CS. It is a 20 -amino-acid peptide originally produced by digestion of purified skeletal muscle PKI with Staphylococcus aureus V8 protease (Cheng et al., 1986). IP-20 binds to the catalytic subunit of the protein kinase, but not the holoenzyme, and inhibits CS competitively, with a $K_{\mathrm{i}}$ of $2.3 \mathrm{nM}$ (Cheng et al., 1986). Its high potency and purity $(>97 \%$ ) make synthetic IP-20 clearly preferable to the impure commercial PKI preparations as an antagonist of CS.

\section{MATERIALS AND METHODS}

Isolation of platelet membrane vesicles responsive to $\mathbf{I P}_{\mathbf{3}}$

Platelet membranes were prepared by differential centrifugation of sonicated platelets on a $\mathrm{KCl} /$ Percoll

\footnotetext{
Abbreviations used: CS, catalytic subunit of cyclic AMP-dependent protein kinase; PKI, protein kinase inhibitor of CS; IP-20, polypeptide inhibitor of CS derived from the active site of PKI; $\mathrm{IP}_{3}$, inositol 1,4,5-trisphosphate.

* Present address: Department of Hematology, Brigham and Women's Hospital, Boston, MA 02115, U.S.A.
} 
gradient as described by O'Rourke et al. (1985). The vesicles were resuspended at $0.4 \mathrm{mg}$ of protein $/ \mathrm{ml}$ in medium containing $100 \mathrm{~mm}-\mathrm{KCl}, 20 \mathrm{~mm}-\mathrm{Hepes}, 5 \mathrm{~mm}-$ $\mathrm{MgCl}_{2}$ and 0-20 mM-phosphate (as described in the text), $\mathrm{pH} 7.1$.

\section{$\mathrm{Ca}^{2+}$ uptake by membrane vesicles}

Vesicles were incubated in the medium described above plus $0.200 \mathrm{mM}-\mathrm{CaCl}_{2}, 1 \mu \mathrm{Ci}$ of ${ }^{45} \mathrm{CaCl}_{2} / \mathrm{ml}$, $0.568 \mathrm{~mm}$-EGTA, $1.9 \mathrm{~mm}$-disodium ATP and 0-20 mMpotassium phosphate, $\mathrm{pH} 7.1$, at $23{ }^{\circ} \mathrm{C}$ (total volume $1.1 \mathrm{ml})$. The calculated free $\left[\mathrm{Ca}^{2+}\right]$ was $1.1 \mu \mathrm{M}$ (O'Rourke et al., 1985). Samples $(100 \mu \mathrm{l})$ of the suspension were taken at specified times, ${ }^{45} \mathrm{Ca}^{2+}$ uptake was 'quenched' with formaldehyde/EDTA solution, and vesicle ${ }^{45} \mathrm{Ca}^{2+}$ was measured by liquid-scintillation counting (see below).

\section{Assay for release of $\mathrm{Ca}^{2+}$ by $\mathrm{IP}_{3}$}

After preloading of vesicles with ${ }^{45} \mathrm{Ca}^{2+}$ for $60 \mathrm{~min}$, an additional $0.4 \mathrm{~mm}$-K-EGTA was added to stop further $\mathrm{Ca}^{2+}$ uptake, followed by addition of $\mathrm{IP}_{3}$. Samples of membrane suspension $(100 \mu \mathrm{l})$ were removed at specified times and added to polycarbonate tubes (Beckman $7 \mathrm{~mm} \times 20 \mathrm{~mm}$ ) containing $25 \mu \mathrm{l}$ of ice-cold quench medium, consisting of $0.633 \mathrm{M}$-formalin and $50 \mathrm{~mm}-$ K-EDTA, pH 7.1. Control experiments showed that the quench medium immediately stops $\mathrm{Ca}^{2+}$ uptake, prevents $\mathrm{Ca}^{2+}$ efflux and does not cause $\mathrm{Ca}^{2+}$ efflux. The membranes were centrifuged at $430000 \mathrm{~g}$ for $2 \mathrm{~min}$ at $4{ }^{\circ} \mathrm{C}$ in a Beckman TL-100 ultracentrifuge. Portions $(10 \mu \mathrm{l})$ of supernatant were transferred to a scintillation vial, and the remainder of the supernatant was vacuumaspirated by using a fine-bore glass pipette. The pellets were extracted with $50 \mu \mathrm{l}$ of $25 \%$ trichloroacetic acid and transferred to scintillation vials for assay of radioactivity.

\section{Phosphorylation of platelet vesicle proteins by CS}

The membrane vesicles were incubated with CS in essentially the same medium as was used for $\mathrm{Ca}^{2+}$ uptake and $\mathrm{IP}_{3}$-induced $\mathrm{Ca}^{2+}$ release. Phosphorylation was initiated by addition of $50 \mu \mathrm{M}$-ATP containing $2.5 \mu \mathrm{Ci}$ of $\left[{ }^{32} \mathrm{P}\right] \mathrm{PTP}$ per $100 \mu \mathrm{l}$ of membrane suspension. Additions of $\mathrm{IP}_{3}$ or $\mathrm{CS}$ were made as indicated in the legends to the Figures. When used, kinase inhibitors were added for $15 \mathrm{~min}$ before CS. The reactions were stopped after $10 \mathrm{~min}$ with $20 \mu \mathrm{l}$ of $20 \%$ (v/v) SDS $/ 25 \mathrm{~mm}$-dithiothreitol and heated in a boiling-water bath. The proteins were electrophoresed on 5-15\%-polyacrylamide gradient slab gels containing $0.1 \%$ SDS, and phosphoproteins were identified by radioautography.

\section{Materials}

$\left[\gamma^{32}\right.$ P]ATP was obtained from New England Nuclear. The catalytic subunit (CS) of cyclic AMP dependent protein kinase from bovine heart was purchased from Sigma (P2645): lots 36F-9525, 63F-3931 and 106F-9660 with activities of 34,26 and 36 units $/ \mu \mathrm{g}$ of protein respectively, and containing $0.16-0.2 \%$ protein; one phosphorylating unit transfers $1 \mathrm{pmol}$ of $\left[\gamma^{32} \mathrm{P}\right] \mathrm{ATP}$ to hydrolysed and partially dephosphorylated casein per min at $\mathrm{pH} 6.5$ at $30^{\circ} \mathrm{C}$. CS was reconstituted in deionized water containing $50 \mathrm{mg}$ of dithiothreitol/ml to a concentration of $0.5 \mathrm{mg}$ of protein $/ \mathrm{ml}$. The protein kinase inhibitors (PKI) used were type II from bovine heart (Sigma, P-8140) and type III from pig heart (Sigma,
P-0393). The last two preparations inhibited 0.9 and 0.5 phosphorylating unit of kinase per $\mu \mathrm{g}$ of protein respectively. They contained $40 \%$ and $70 \%$ protein respectively, with the balance consisting of glycerophosphate and EDTA salts. The peptide inhibitor (IP20) of cyclic AMP-dependent protein kinase was obtained from Bachem, Torrance, CA, U.S.A. (PPHO70 lot no. 781C); $1 \mu \mathrm{g}$ inhibits approx. 5000 phosphorylating units of cyclic AMP-dependent kinase. This peptide has the amino acid sequence Thr-Thr-Tyr-Ala-Asp-Phe-Ile-AlaSer-Gly-Arg-Thr-Gly-Arg-Arg-Asn-Ala-Ile-His-Asp (Cheng et al., 1986).

\section{RESULTS}

Previous studies of $\mathrm{Ca}^{2+}$ transport in platelet membranes have mostly used a standard membrane filtration technique to measure uptake of ${ }^{45} \mathrm{Ca}^{2+}$. In our hands this method proved to be unacceptably variable and unreliable, largely owing to significant non-specific binding of ${ }^{45} \mathrm{Ca}^{2+}$ to filter membranes, especially as the phosphate concentration in the medium was increased. We therefore developed an alternative procedure that permitted accurate measurement of $\mathrm{Ca}^{2+}$ uptake and release by $\mathrm{IP}_{3}$. This method employs formaldehyde as a reaction 'quenching' agent combined with EDTA to remove surface-bound $\mathrm{Ca}^{2+}$, followed by rapid highspeed centrifugation (Beckman TL-100 ultracentrifuge). This quenching reagent immediately stopped ${ }^{45} \mathrm{Ca}^{2+}$ influx, and did not permit any efflux or response to IP3. The ${ }^{45} \mathrm{Ca}^{2+}$ content of vesicles remains stable for at least $1 \mathrm{~h}$ in the formaldehyde/EDTA solution. In contrast, vesicles quenched in ice-cold $\mathrm{Ca}^{2+}$-free medium initially have a significantly larger amount of surface-associated ${ }^{45} \mathrm{Ca}^{2+}$, which dissociates from the membranes over a $30 \mathrm{~min}$ period (Fig. 1a). The formalin/EDTA solution immediately removes this surface-bound $\mathrm{Ca}^{2+}$. The membrane pellets obtained by centrifugation at $450000 \mathrm{~g}$ for 2 min contain no significant extravesicular trapped $\mathrm{Ca}^{2+}$, since there was no further decrease in vesicle ${ }^{45} \mathrm{Ca}^{2+}$ after two washes of the pellets in $\mathrm{Ca}^{2+}$-free medium. The time course of $\mathrm{Ca}^{2+}$ efflux from platelet vesicles in response to $\mathrm{IP}_{3}$, measured by this method, is shown in Fig. 1(b). The presence of EGTA in the medium along with $\mathrm{IP}_{3}$ prevented re-uptake of released $\mathrm{Ca}^{2+}$ and allowed measurement of the maximal extent of $\mathrm{Ca}^{2+}$ release by $\mathrm{IP}_{3}$.

\section{Effects of $\mathrm{CS}$ on $\mathrm{Ca}^{2+}$ uptake by platelet vesicles}

Commercial preparations of CS, widely used in this and most previous studies, have a very high content of phosphate (9.84-19.9\% of freeze-dried powder), and the uptake of $\mathrm{Ca}^{2+}$ is markedly stimulated by phosphate. In the absence of phosphate, $\mathrm{Ca}^{2+}$ uptake by platelet vesicles was never more than $15 \mathrm{nmol} / \mathrm{mg}$ of protein, comparable with values obtained by Hack et al. (1986) and Adunyah \& Dean (1986a) under similar conditions. $\mathrm{Ca}^{2+}$ accumulation increased to $120-150 \mathrm{nmol} / \mathrm{mg}$ of protein when the medium contained $20 \mathrm{~mm}$-phosphate and free $\mathrm{Ca}^{2+}$ was buffered with EGTA to $1 \mu \mathrm{M}$, a concentration attained intracellularly in stimulated platelets (in contrast, earlier studies on platelet vesicles have mostly used unbuffered higher $\mathrm{Ca}^{2+}$ concentrations in the range 5-60 $\mu \mathrm{M})$. CS concentrations in the range of 100 200 units/ml can contribute several millimolar phosphate to the medium. This has a demonstrable stimulatory 

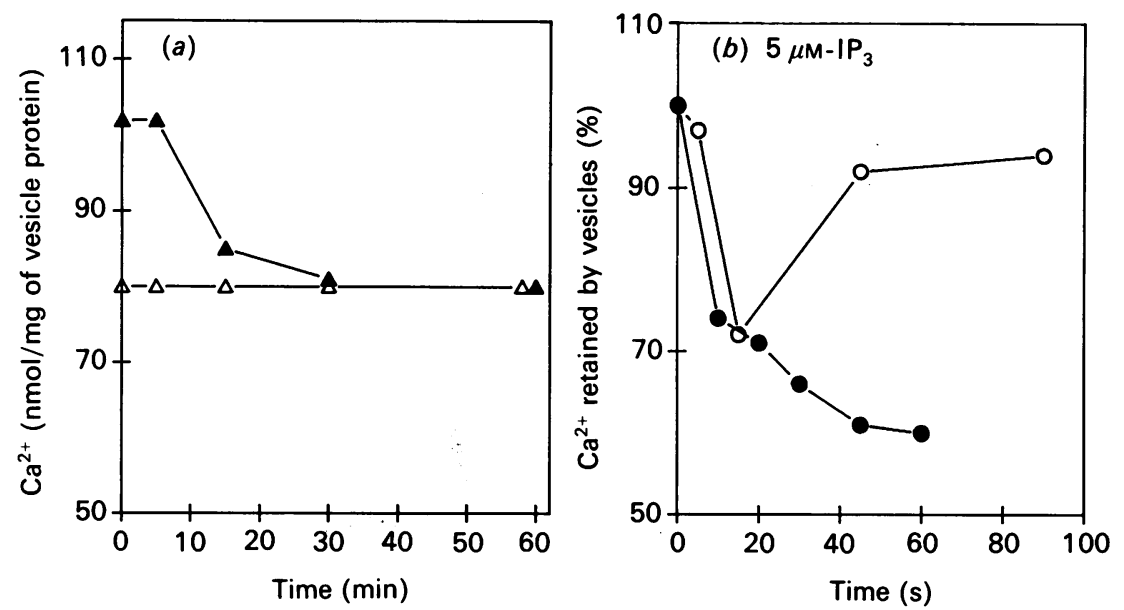

Fig. 1. Stability of intravesicular ${ }^{45} \mathrm{Ca}^{2+}$ in formaldehyde/EGTA-treated vesicles

(a) Vesicles were preloaded with ${ }^{45} \mathrm{Ca}^{2+}$ for 60 min and then added to $\mathrm{Ca}^{2+}$-free buffer $(\boldsymbol{\Delta})$ or to formaldehyde/EGTA solution $(\triangle)$. Samples were taken at indicated times for measurement of vesicle ${ }^{45} \mathrm{Ca}^{2+}$. (b) Time course of release of ${ }^{45} \mathrm{Ca}^{2+}$ from platelet vesicles. Vesicles preloaded with ${ }^{45} \mathrm{Ca}^{2+}$ were stimulated with $5 \mu \mathrm{M}-\mathrm{IP}_{3}$ in the absence $(O)$ or the presence $(O)$ of $4 \mathrm{mM}$-EGTA. Samples of the suspension were taken at times indicated, quenched with formaldehyde/EGTA, and analysed for ${ }^{45} \mathrm{Ca}^{2+}$.

effect on $\mathrm{Ca}^{2+}$ uptake if the medium contains little or no phosphate.

To study effects of CS at low phosphate concentration in the medium, we desalted CS by several cycles of centrifugation in Centricon-10 (Amicon) concentrators with phosphate-free $\mathrm{Ca}^{2+}$-transport buffer containing 50 mm-dithiothreitol. Desalted enzyme completely retained its activity, including the ability to phosphorylate the platelet membrane $23 \mathrm{kDa}$ polypeptide. The desalted CS was without influence on $\mathrm{Ca}^{2+}$ uptake by membrane

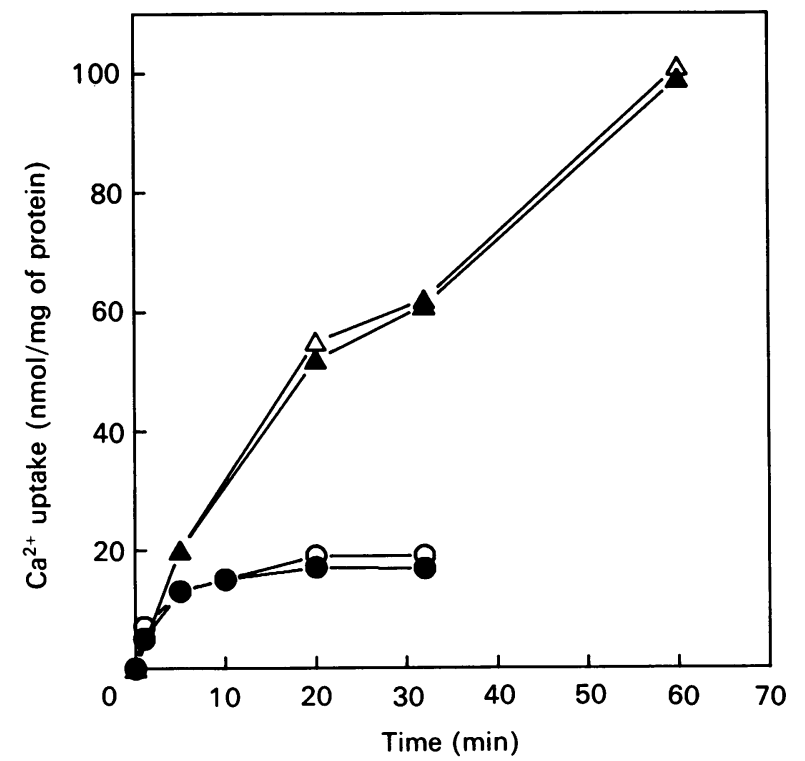

Fig. 2. Effect of $\mathrm{CS}$ on $\mathrm{Ca}^{2+}$ uptake at 0-20 mM-phosphate in the medium

$\mathrm{Ca}^{2+}$ uptake was measured as described in the Materials and methods section in the absence $(O, \triangle)$ or the presence $(O, \Delta)$ of 200 units of desalted CS $/ \mathrm{ml}$. The phosphate content of the medium was $2 \mathrm{~mm}(\mathrm{O}, \mathrm{)})$ or $20 \mathrm{~mm}(\triangle$, $\Delta)$. For clarity, experiments at zero phosphate are not shown; $\mathrm{Ca}^{2+}$ uptake reached a peak at $3 \mathrm{nmol} / \mathrm{mg}$ of protein, and was unaffected by CS. vesicles, irrespective of the phosphate content of the medium (Fig. 2).

\section{$\mathrm{Ca}^{2+}$ uptake in the presence of PKI and the peptide inhibitor IP-20}

Commercial preparations of PKI have been reported to inhibit $\mathrm{Ca}^{2+}$ uptake (Hettasch \& LeBreton, 1987; Adunyah \& Dean, 1987), suggesting that cyclic AMP-dependent protein kinase promotes $\mathrm{Ca}^{2+}$ uptake. However, conclusions drawn from these experiments are questionable, because the commercial PKI preparations are grossly impure, exhibiting many polypeptides on SDS/polyacrylamide gels (Fig. $3 a$ ). In our experiments inhibition of $\mathrm{Ca}^{2+}$ uptake by PKI was highly variable, although inhibition of protein phosphorylation by CS was clearly demonstrable (results not shown). One pig heart PKI preparation slightly inhibited $\mathrm{Ca}^{2+}$ uptake (Table 1), whereas others from pig or bovine heart of equal potency against $\mathrm{CS}$ had virtually no effect on $\mathrm{Ca}^{2+}$ uptake (e.g. Fig. 4), suggesting that kinase inhibition was not responsible for the effect on $\mathrm{Ca}^{2+}$ uptake.

IP-20, the peptide inhibitor of CS, was without effect on $\mathrm{Ca}^{2+}$ uptake in either the presence or the absence of exogenous CS (Fig. 4). The IP-20 completely blocked endogenous protein phosphorylation and that by 125 units of $\mathrm{CS} / \mathrm{ml}$, the latter representing an activity far in excess of the endogenous membrane kinase activity (Fig. 3b, tracks $\mathrm{A}-\mathrm{H}$ ).

\section{$\mathrm{Ca}^{2+}$ release by $\mathrm{IP}_{3}$ in the presence of $\mathrm{CS}, \mathrm{PKI}$ and the} peptide inhibitor IP-20

Desalted CS (125 units $/ \mathrm{ml})$ produced maximal phosphorylation of a $23 \mathrm{kDa}$ membrane polypeptide within $10 \mathrm{~min}$ (Fig. $3 b$ ), but CS (in the absence or presence of inhibitors) did not affect $\mathrm{Ca}^{2+}$ release from platelet vesicles (Fig. 4). In the absence of added CS, Enouf et al. (1987) reported that PKI (Sigma, type II P 8140 ) at $80 \mu \mathrm{g} / \mathrm{ml}$ decreased $\mathrm{Ca}^{2+}$ release by $50 \%$, and at $160 \mu \mathrm{g} / \mathrm{ml}$ completely abolished release of $\mathrm{Ca}^{2+}$ by $20 \mu \mathrm{M}-\mathrm{IP}_{3}$. This effect of PKI was attributed to inactivation of weak endogenous cyclic AMP-dependent kinase activity. In our experiments, the release of $\mathrm{Ca}^{2+}$ by $\mathrm{IP}_{3}$ in 
(a)

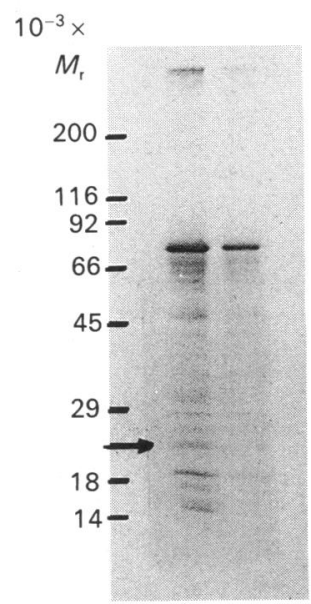

(b)

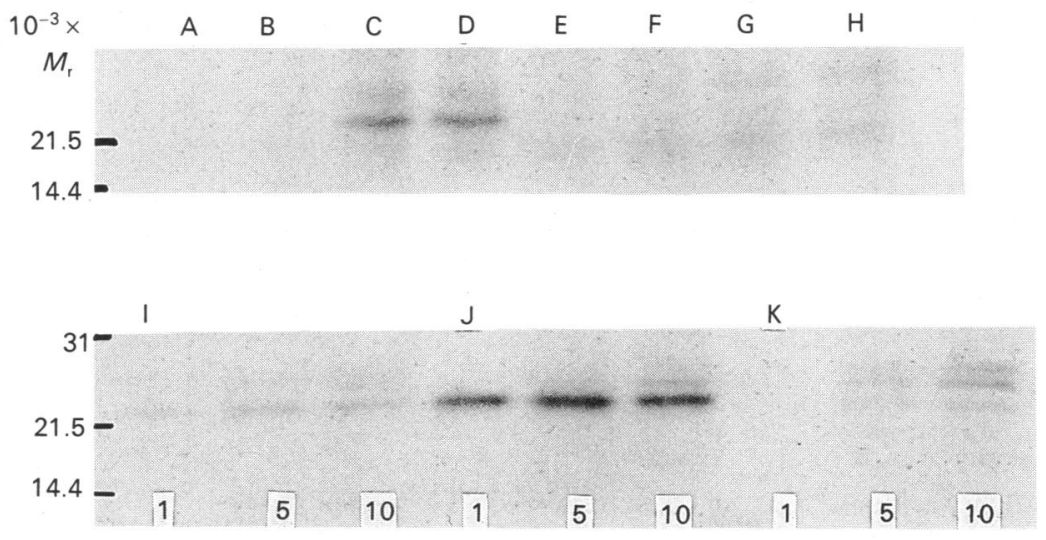

Fig. 3. Polypeptide compostion of type II PKI

(a) Type II PKI (20 and $10 \mu \mathrm{g}$ per lane) was subjected to SDS/polyacrylamide-gel electrophoresis. Gels were stained with Coomassie Blue. At least 20 polypeptide bands are visible; arrow indicates expected position of purified PKI reported by Szmigielski et al. (1977). (b) Radioautographs of platelet membrane vesicle phosphoproteins. Top panel: membranes were incubated for $10 \mathrm{~min}$ with $14 \mathrm{mM}$-phosphate, $100 \mu \mathrm{M}-\mathrm{CaCl}_{2}, 139 \mu \mathrm{M}-\mathrm{EGTA}, 100 \mu \mathrm{M}-\mathrm{ATP}\left(20 \mu \mathrm{Ci}\right.$ of $\left.\left[\gamma_{-}{ }^{32} \mathrm{P}\right] \mathrm{ATP} / \mathrm{ml}\right)$ and 125 units of $\mathrm{CS} / \mathrm{ml}$. Duplicate samples were taken for SDS/polyacrylamide-gel electrophoresis and radioautography. CS phosphorylated $23 \mathrm{kDa}$ polypeptide (C, D), which was abolished by $4 \mu \mathrm{M}-\mathrm{IP}-20$ (A, B). Phosphorylation by endogenous kinase activity (no added CS) (G, H), and inhibition by $4 \mu \mathrm{M}-\mathrm{IP}-20$ (E, F), are shown. Positions of $M_{\mathrm{r}}$ standards are shown. Bottom panel: time course of membrane phosphorylation in $\mathrm{IP}_{3}$-treated membranes. Reactions were started by addition of [ $\left.{ }^{32} \mathrm{P}\right] \mathrm{ATP}$, and membrane samples were taken at 1,5 and $10 \mathrm{~min}$ intervals as marked and analysed by SDS/polyacrylamide-gel electrophoresis and radioautography: I, phosphorylation without $\mathrm{IP}_{3} ; \mathrm{J}$, plus $5 \mu \mathrm{M}-\mathrm{IP}_{3}$ added at zero time; K, IP ${ }_{3}$ plus 4 mMEGTA.

the absence of CS was unaffected by $100 \mu \mathrm{g}$ of type II $\mathrm{PKI} / \mathrm{ml}$ (Fig. 4). More significantly, a high concentration of IP-20 (4 $\mu \mathrm{M})$ also had no effect on $\mathrm{IP}_{3}$-induced $\mathrm{Ca}^{2+}$ release (Fig. 4).

\section{ATP and protein phosphorylation are not necessary for $\mathrm{IP}_{3}$-induced $\mathrm{Ca}^{2+}$ release}

Responses to $\mathrm{IP}_{3}$ were measured in the absence of ATP to assess further the possible involvement of protein kinases. In one set of experiments, vesicles were preloaded with ${ }^{45} \mathrm{Ca}^{2+}$ plus ATP, and then thoroughly washed to remove the nucleotide. These vesicles released $\mathrm{Ca}^{2+}$ normally in response to $\mathrm{IP}_{3}$. In other experiments, vesicles were passively loaded with ${ }^{45} \mathrm{Ca}^{2+}$ without ATP. ${ }^{45} \mathrm{Ca}^{2+}$ was added to the medium (devoid of ATP) just before sonication of washed platelets. This permitted ${ }^{45} \mathrm{Ca}^{2+}$ to enter the vesicles during the process of membrane disruption and resealing. The vesicles were isolated as usual and washed to remove any extravesicular ${ }^{45} \mathrm{Ca}^{2+}$. The vesicles were fully capable of releasing $\mathrm{Ca}^{2+}$ in response to $\mathrm{IP}_{3}$ in the total absence of ATP (Table 2). These experiments show that protein phosphorylation involving an endogenous vesicle kinase is not required for response to $\mathrm{IP}_{3}$.

In some experiments a polypeptide of approx. $23 \mathrm{kDa}$ was phosphorylated when vesicles were exposed to $\mathrm{IP}_{3}$ in the presence of $\left[{ }^{32} \mathrm{P}\right] \mathrm{ATP}$. We do not know if this protein is the same as the substrate for CS. Phosphorylation was totally abolished by EGTA (Fig. $3 b$, tracks I-K), demonstrating that it was dependent on extravesicular $\mathrm{Ca}^{2+}$. Although no phosphorylation was observed in the
Table 1. Effects of protein kinase inhibitors on $\mathrm{Ca}^{2+}$ uptake and $\mathrm{Ca}^{2+}$ release by $\mathrm{IP}_{3}$

Three batches of platelet vesicles $(0.1 \mathrm{mg} / \mathrm{ml}),(a),(b)$ and $(c)$, took up ${ }^{45} \mathrm{Ca}^{2+}$ for $60 \mathrm{~min}$ in the presence of $1.9 \mathrm{~mm}$-ATP and $20 \mathrm{~mm}$-potassium phosphate (free $\left.\left[\mathrm{Ca}^{2+}\right]=1.1 \mu \mathrm{M}\right)$. EGTA (4 mM) was then added, followed by $5 \mu \mathrm{M}-\mathrm{IP}_{3}$. The reactions were quenched with formaldehyde (see the Materials and methods section). The concentrations of other ingredients were: CS, 125 units/ $\mathrm{ml}$; PKI (type III protein kinase inhibitor, Sigma) $0.33 \mathrm{mg} / \mathrm{ml}$; IP-20 (peptide inhibitor) $4 \mu \mathrm{M}$.

\begin{tabular}{|c|c|c|c|c|c|c|}
\hline \multirow[b]{2}{*}{ Batch... } & \multicolumn{3}{|c|}{$\begin{array}{c}\mathrm{Ca}^{2+} \text { uptake } \\
(\mathrm{nmol} / \mathrm{mg} \text { of } \\
\text { protein })\end{array}$} & \multicolumn{3}{|c|}{$\begin{array}{c}\mathrm{IP}_{3} \text {-induced } \\
\mathrm{Ca}^{2+} \text { release } \\
\text { (nmol } / \mathrm{mg} \text { of protein) }\end{array}$} \\
\hline & $(a)$ & $(b)$ & $(c)$ & (a) & $(b)$ & $(c)$ \\
\hline Control & 112 & 142 & 115 & 33.6 & 42.6 & 24.6 \\
\hline $\begin{array}{l}+ \text { IP-20 } \\
\text { + PKI }\end{array}$ & $\begin{array}{l}119 \\
118\end{array}$ & $\begin{array}{l}148 \\
143\end{array}$ & 119 & $\begin{array}{l}35.7 \\
21.2\end{array}$ & $\begin{array}{l}44.4 \\
25.7\end{array}$ & 21.4 \\
\hline $\begin{array}{l}+\mathrm{CS} \\
+\mathrm{CS}+\mathrm{PKI} \\
+\mathrm{CS}+\mathrm{IP}-20\end{array}$ & $\begin{array}{l}113 \\
122\end{array}$ & $\begin{array}{l}148 \\
142 \\
148\end{array}$ & $\begin{array}{l}113 \\
120\end{array}$ & $\begin{array}{l}29.4 \\
22.0\end{array}$ & $\begin{array}{l}44.4 \\
25.6 \\
39.0\end{array}$ & 20.9 \\
\hline
\end{tabular}

presence of EGTA, ${ }^{45} \mathrm{Ca}^{2+}$ release by $\mathrm{IP}_{3}$ was actually increased, since EGTA prevents $\mathrm{Ca}^{2+}$ re-uptake (e.g. see Fig. 1b). These results are in agreement with other findings that ATP is not required for release of $\mathrm{Ca}^{2+}$ by $\mathrm{IP}_{3}$ (Adunyah \& Dean, 1986b; Meyer et al., 1988). 

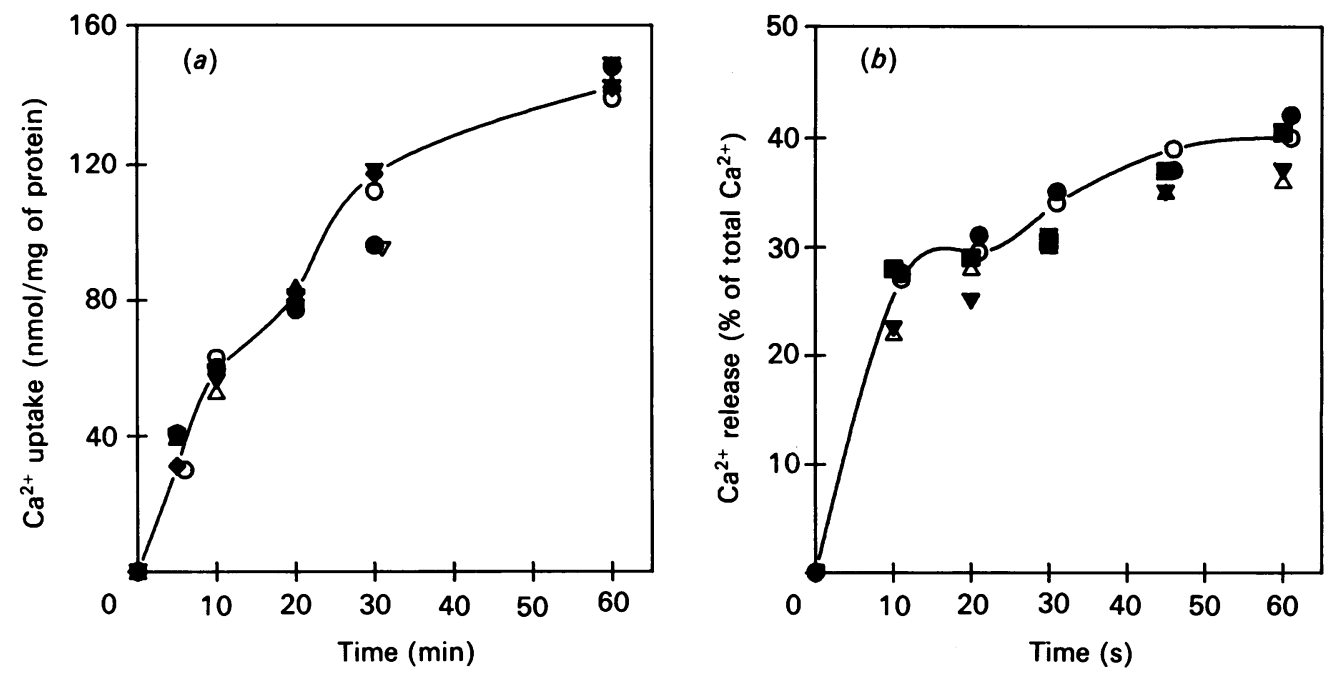

Fig. 4. Effects of IP-20, PKI and CS on time course of ${ }^{45} \mathrm{Ca}^{2+}$ uptake and $\mathrm{Ca}^{2+}$ release by $\mathrm{IP}_{3}$

(a) $\mathrm{Ca}^{2+}$ uptake in the presence of $20 \mathrm{~mm}$-phosphate $(\diamond$, continuous line), plus CS $(125 \mathrm{units} / \mathrm{ml})(\mathrm{O}), \mathrm{plus} \mathrm{PKI}(100 \mu \mathrm{g} / \mathrm{ml})(\triangle)$, plus $4 \mu \mathrm{M}$-IP-20 (O), CS + PKI $(\nabla)$ and CS + IP-20 ( $\nabla)$. (b) Vesicles were preloaded with ${ }^{45} \mathrm{Ca}^{2+}$ and then exposed to $5 \mu \mathrm{M}-$ $\mathrm{IP}_{3} . \mathrm{Ca}^{2+}$ release was measured as described in the Materials and methods section. Control $(\mathrm{O})$ release is fitted by the continuous line. Symbols depict $\mathrm{Ca}^{2+}$ release in the presence of IP-20 (O), PKI $(\square)$, CS $(\triangle)$ and CS + IP-20 ( $\left.\nabla\right)$. All additions were made $10 \mathrm{~min}$ before $\mathrm{IP}_{3}$.

Table 2. $\mathrm{IP}_{3}$-induced $\mathrm{Ca}^{2+}$ release in the presence or absence of ATP

(a) Platelet vesicles minus ATP were sonicated in the presence of ${ }^{45} \mathrm{CaCl}_{2}(100 \mu \mathrm{Ci} / 3 \mathrm{ml}$ of platelet suspension $)$. Vesicle fraction isolated as described by O'Rourke et al. (1985) was suspended to $0.5 \mathrm{mg}$ of protein $/ \mathrm{ml}$ and assayed for $\mathrm{IP}_{3}$-stimulated $\mathrm{Ca}^{2+}$ release at room temperature in the absence of ATP or after addition of $100 \mu \mathrm{M}$-ATP. (b) Vesicles loaded with ${ }^{45} \mathrm{Ca}^{2+}$ were washed at $4{ }^{\circ} \mathrm{C}$ three times with ATP-free medium and then tested for $\mathrm{Ca}^{2+}$ release by $\operatorname{IP}_{3}(5 \mu \mathrm{M})$.

\begin{tabular}{|c|c|c|c|c|}
\hline \multirow[b]{2}{*}{ (a) } & \multirow[b]{2}{*}{ Vesicles } & \multicolumn{2}{|c|}{${ }^{45} \mathrm{Ca}^{2+}$ in vesicles } & \multirow[b]{2}{*}{$\mathrm{Ca}^{2+}$ released $(\%)$} \\
\hline & & Control & $+\mathrm{IP}_{3}$ & \\
\hline & $\begin{array}{l}\text { - ATP } \\
+ \text { ATP }\end{array}$ & $\begin{array}{l}4754 \\
4912\end{array}$ & $\begin{array}{l}3654 \\
3920\end{array}$ & $\begin{array}{l}24 \\
21\end{array}$ \\
\hline & & $\mathrm{Ca}^{2+}$ in & sicles & \\
\hline \multirow[t]{2}{*}{ (b) } & Vesicles & Control & $+\mathrm{IP}_{3}$ & (nmol) \\
\hline & $\begin{array}{l}\text { - ATP } \\
+ \text { ATP }\end{array}$ & $\begin{array}{l}80 \\
75\end{array}$ & $\begin{array}{l}70.4 \\
65.2\end{array}$ & $\begin{array}{l}9.6 \\
9.8\end{array}$ \\
\hline
\end{tabular}

\section{DISCUSSION}

We find no evidence to support the contention that cyclic AMP-dependent protein kinase is either necessary for, or stimulatory to, $\mathrm{IP}_{3}$-induced $\mathrm{Ca}^{2+}$ release from platelet membrane vesicles. This conclusion is based on two observations: (1) desalted catalytic subunit of cyclic AMP-dependent protein kinase did not stimulate $\mathrm{Ca}^{2+}$ release by $\mathrm{IP}_{3}$, and (2) IP-20, the potent polypeptide inhibitor of $\mathrm{CS}$, had no effect on $\mathrm{Ca}^{2+}$ release by $\mathrm{IP}_{3}$ in either the absence or the presence of CS. IP-20 was present at a concentration that completely blocked CS activity far in excess of that present in the membranes. The peptide inhibitor IP-20 represents the active site of the $24 \mathrm{kDa}$ skeletal-muscle protein kinase inhibitor protein (PKI), and is highly specific for the catalytic subunit of the cyclic AMP-dependent protein kinase (Cheng et al., 1986). The failure of the peptide to inhibit $\mathrm{Ca}^{2+}$ release by $\mathrm{IP}_{3}$ makes the involvement of cyclic AMP-dependent protein kinase in this reaction highly dubious.

Enouf et al. (1987) reported that a commercial preparation of PKI could abolish release of $\mathrm{Ca}^{2+}$ by $\mathrm{IP}_{3}$. In our hands, one lot of the inhibitor from pig heart (Sigma, type III) only partially decreased both $\mathrm{Ca}^{2+}$ uptake and the release of $\mathrm{Ca}^{2+}$ by $\mathrm{IP}_{3}$, but inhibitor from bovine heart (Sigma, type II), the same preparation as used by Enouf et al. (1987) (Sigma P 8140), was entirely lacking in either effect. Gel electrophoresis of these PKI preparations reveals them to be highly impure with regard to protein content. They also contain significant amounts of glycerophosphate and EDTA. We cannot account for the lack of effect of type II PKI in our experiments, but it is possible that various lots differ in their content of some inhibitory material. Also, Enouf et al. (1987) exposed vesicles to PKI for $80 \mathrm{~min}$, a long time considering that reaction of the kinase inhibitor with CS is virtually immediate [see Table II of Ashby \& Walsh (1972)]. Such prolonged interaction might enhance nonspecific effects of impurities.

Another very crude commercial preparation of PKI from rabbit muscle (Sigma) was reported to release very rapidly up to $45 \%$ of accumulated $\mathrm{Ca}^{2+}$ when added to preloaded platelet vesicles (Hettasch \& LeBreton, 1987). It is difficult to attribute the rapid release of $\mathrm{Ca}^{2+}$ by PKI to inhibition of CS, because it occuried with $55 \mu \mathrm{M}-\mathrm{Ca}^{2+}$ in the medium, a condition in which $\mathrm{Ca}^{2+}$ uptake was 
completely unaffected by added CS (Hettasch \& LeBreton, 1987). Spontaneous release of $\mathrm{Ca}^{2+}$ from platelet vesicles does not occur after ATP depletion (Adunyah \& Dean, 1986a), which suggests that the PKI preparation was able to release $\mathrm{Ca}^{2+}$ by a mechanism unrelated to protein phosphorylation. In our experiments $4 \mu \mathrm{M}-\mathrm{IP}-20$ did not release any $\mathrm{Ca}^{2+}$ when added to preloaded membrane vesicles (results not shown). We conclude that inhibition of cyclic AMP-dependent protein kinase is not a mechanism for $\mathrm{Ca}^{2+}$ release.

The independence of $\mathrm{IP}_{3}$-mediated $\mathrm{Ca}^{2+}$ release from protein kinase activity is also supported by the lack of requirement for ATP and protein phosphorylation, and is in agreement with other work (Adunyah \& Dean, $1986 b$; Meyer et al., 1988). Protein phosphorylation when seen in platelet vesicles exposed to $\mathrm{IP}_{3}$ was entirely indirect, as it occurred after release of $\mathrm{Ca}^{2+}$ from vesicles into the medium and was abolished by EGTA. In contrast, EGTA actually enhanced net release of $\mathrm{Ca}^{2+}$ by $\mathrm{IP}_{3}$, by preventing its re-uptake.

Although the main purpose of our work was to evaluate the role of cyclic AMP-dependent protein kinase in the release of $\mathrm{Ca}^{2+}$ by $\mathrm{IP}_{3}$, the effect of $\mathrm{CS}$ on $\mathrm{Ca}^{2+}$ uptake was also of interest. The role of protein phosphorylation in $\mathrm{Ca}^{2+}$ uptake by platelet vesicles is unclear. Several groups have reported that cyclic AMPdependent protein kinase stimulates the early phase of $\mathrm{Ca}^{2+}$ uptake and the phosphorylation of a $23 \mathrm{kDa}$ polypeptide suggested to resemble phospholamban (Kaser-Glanzmann et al., 1977, 1979; Adunyah \& Dean, 1987; Hettasch \& LeBreton, 1987). The last two studies used commercial preparations of CS. In contrast, LePeuch et al. (1983), using enzyme purified in their laboratory, observed no stimulation of $\mathrm{Ca}^{2+}$ uptake by CS, but rather an increase of $\mathrm{Ca}^{2+}$ efflux. They also reported that the $23 \mathrm{kDa}$ polypeptide substrate for the enzyme bore no similarity in properties to phospholamban.

We find no evidence of a role for cyclic AMPdependent protein kinase in $\mathrm{Ca}^{2+}$ uptake. When phosphate was low or absent the widely used commercial preparation of CS increased $\mathrm{Ca}^{2+}$ uptake, but in our experiments that effect was attributable entirely to the contribution of phosphate anion from the freeze-dried preparations of the enzyme. CS from which phosphate was removed retained its enzymic activity, phosphorylated the $23 \mathrm{kDa}$ polypeptide, but no longer stimulated $\mathrm{Ca}^{2+}$ uptake at any concentration of phosphate in the medium.

Adunyah \& Dean (1987) found that bovine heart PKI (Sigma, type II) reversed the effect of $\mathrm{CS}$ on $\mathrm{Ca}^{2+}$ uptake, strengthening the presumed cause-and-effect link between protein phosphorylation and $\mathrm{Ca}^{2+}$ uptake. However, close observation of the data (their Fig. 3) reveals that PKI inhibited only the first $25-50 \mathrm{~s}$ of ${ }^{45} \mathrm{Ca}^{2+}$ uptake. Thereafter, the rate of ${ }^{45} \mathrm{Ca}^{2+}$ uptake was the same as in the absence of the inhibitor. This finding suggests that an initial binding reaction, rather than transport, was affected by both the CS and PKI preparations. Our failure to observe such effects may be due to our method of measuring $\mathrm{Ca}^{2+}$ uptake, which eliminates surfacebound $\mathrm{Ca}^{2+}$.

Elevation of cyclic AMP concentration represents a powerful mechanism for inhibition of $\mathrm{Ca}^{2+}$ mobilization in intact platelets (Rink \& Smith, 1983; Feinstein et al.,1983; Yamanishi et al., 1983), and is apparently due to interference with the release of internal $\mathrm{Ca}^{2+}$ stores and the surface membrane permeability to $\mathrm{Ca}^{2+}$. The inhibition of intracellular $\mathrm{Ca}^{2+}$ release can largely be explained by suppression of phosphatidylinositol 4,5bisphosphate hydrolysis (Imai et al., 1983; Bushfield et al., 1985; Zavoico et al., 1985; Feinstein et al., 1985) and $\mathrm{IP}_{3}$ production (Watson et al., 1984) by cyclic AMP. In the case of thrombin-induced responses, cyclic AMP may affect G-protein/receptor interactions (Knight \& Scrutton, 1984), and there is evidence that it prevents receptor-induced dissociation of G-protein oligomers (Halenda et al., 1986) and/or binding of thrombin to its receptors (Lerea et al., 1987), thereby preventing activation of phospholipase $\mathrm{C}$ and subsequent $\mathrm{Ca}^{2+}$ mobilization. It is quite possible that cyclic AMP affects free $\mathrm{Ca}^{2+}$ concentrations in the cytoplasm by other actions, but these remain unproven. Further experimentation may be profitably directed towards studying the specific role of membrane binding of $\mathrm{Ca}^{2+}$ as a mechanism to decrease cytosolic free $\mathrm{Ca}^{2+}$, and the possibility that such a mechanism may be modulated by cyclic AMP.

M.B.F. is supported by N.I.H. grants HL 18937 and HL 37422.

\section{REFERENCES}

Adunyah, S. E. \& Dean, W. L. (1985) Biochem. Biophys. Res. Commun. 128, 1274-1280

Adunyah, S. E. \& Dean, W. L. (1986a) J. Biol. Chem. 261, 3122-3127

Adunyah, S. E. \& Dean, W. L. (1986b) J. Biol. Chem. 261, 13071-13075

Adunyah, S. E. \& Dean, W. L. (1987) Biochim. Biophys. Acta 930, 401-409

Ashby, C. D. \& Walsh, D. A. (1972) J. Biol. Chem. 247, $6637-6642$

Authi, K. \& Crawford, N. (1985) Biochem. J. 230, 247-253

Bushfield, M., McNicol, A. \& MacIntyre, D. E. (1985) Biochem. J. 232, 267-271

Cheng, H.-C., Kemp, B. E., Pearson, R. B., Smith, A. J., Misconi, L., Van Patten, S. M. \& Walsh, D. A. (1986) J. Biol. Chem. 261, 989-992

Enouf, J., Giraud, F., Bredoux, R., Bourdeau, N. \& LevyToledano, S. (1987) Biochim. Biophys. Acta 928, 76-82

Feinstein, M. B., Egan, J. J., Sha'afi, R. I. \& White, J. (1983) Biochem. Biophys. Res. Commun. 113, 598-604

Feinstein, M. B., Zavoico, G. B. \& Halenda, S. P. (1985) in The Platelets: Physiology and Pharmacology (Longenecker, E., ed.), pp. 237-269, Academic Press, New York

Hack, N., Croset, M. \& Crawford, N. (1986) Biochem. J. 233, 661-668

Halenda, S. P., Volpi, M., Zavoico, G. B., Sha'afi, R. I. \& Feinstein, M. B. (1986) FEBS Lett. 204, 341-346

Hettasch, J. M. \& LeBreton, G. C. (1987) Biochim. Biophys. Acta 931, 49-58

Imai, A., Hattori, H., Takahashi, M. \& Nozawa, Y. (1983) Biochem. Biophys. Res. Commun. 90, 92-98

Kaser-Glanzmann, R., Jakabova, M., George, J. N. \& Luscher, E. F. (1977) Biochim. Biophys. Acta 466, 429-440

Kaser-Glanzmann, R., Gerber, E. \& Luscher, E. F. (1979) Biochim. Biophys. Acta 558, 344-347 
Knight, D. E. \& Scrutton, M. C. (1984) Nature (London) 309, 66-68

LePeuch, C. J., LePeuch, D. A. M., Katz, S., DeMaille, J. G., Hincke, M. T., Bredoux, R., Enouf, J., Levy-Toledano, S. \& Caen, J. (1983) Biochim, Biophys. Acta 731, 456-464

Lerea, K. M., Glomset, J. A. \& Krebs, E. G. (1987) J. Biol. Chem. 262, 282-288

Meyer, T., Holowka, D. \& Stryer, L. (1988) Science 240, $653-655$

O'Rourke, F. O., Halenda, S. P., Zavoico, G. B. \& Feinstein, M. B. (1985) J. Biol. Chem. 260, 956-962

Received 6 June 1988; accepted 4 August 1988
Rink, T. J. \& Smith, S. W. (1983) J. Physiol. (London) 338, $66 P-67 P$

Szmigielski, A., Guidotti, A. \& Costa, E. (1977) J. Biol. Chem. 252, 3848-3853

Watson, S. P., McConnell, R. T. \& Lapetina, E. G. (1984) J. Biol. Chem. 259, 13199-13203

Yamanishi, J., Kawahara, Y. \& Fukuzaki, H. (1983) Thromb. Res. 32, 183-188

Zavoico, G. B., Halenda, S., Chester, D. \& Feinstein, M. B. (1985) in Prostaglandins, Leukotrienes and Lipoxins (Bailey, J. M., ed.), pp. 345-356, Plenum, New York 